\title{
FAKTOR-FAKTOR PENGGUNAAN KONTRASEPSI DIWILAYAH PEDESAAN PROVINSI BANTEN \\ (ANALISIS DATA SDKI 2017)
}

\author{
FACTORS ASSOCIATED WITH CONTRACEPTIVE USE IN \\ A RURAL AREA IN BANTEN PROVINCE \\ (Analysis Of The 2017 Indonesia Demographic And Health Survey) \\ ${ }^{1}$ Ismiyati, ${ }^{2}$ Deden Gumilar Nugraha \\ ${ }^{1}$ Poltekkes Kemenkes Banten \\ ${ }^{2}$ BKKBN Provinsi Banten \\ Korespondensi: ismiyati@ poltekkesbanten.ac.id
}

\begin{abstract}
Family planning can prevent maternal death in about $28 \%-30 \%$ of high-risk pregnancies. the use of modern contraceptives has decreased. This use in 2012 was recorded at around 57.9\% while in 2017 it was recorded at 57.2\%. The use of modern contraceptives in Banten Province was recorded at 57.3\%. This research is a qualitative descriptive study with a total sample of 221 women of childbearing age from the 2017 Indonesia Demographic And Health Survey. The results show that modern contraception is the main choice for women of childbearing age. The use of contraceptives cannot be obtained by certain factors.
\end{abstract}

Key Words: Contraception, Rural Area

\begin{abstract}
ABSTRAK
Keluarga Berencana dapat mencegah penyebab kematian ibu sekitar 28\%-30\% kehamilan dengan risiko tinggi. penggunaan kontrasepsi modern mengalami penurunan. Penggunaan tersebut pada tahun 2012 tercatat sekitar 57,9\% sedangkan di tahun 2017 tercatat 57,2\%. Pemakaian kontrasepsi modern di Provinsi Banten tercatat 57,3\%. Penelitian ini merupakan penelitian deskriptif kualitatif dengan jumlah sampel 221 wanita usia subur dari Data SDKI 2017. Hasil Penelitian di dapatkan bahwa kontrasepsi modern menjadi pilihan utama wanita usia subur. Penggunaan kontrasepsi tersebut tidak dipengaruhi oleh faktor tertentu.
\end{abstract}

Kata kunci : Kontrasepsi, Pedesaan

\section{PENDAHULUAN}

Keluarga Berencana meningkatkan kesehatan perempuan dengan mengurangi proporsi kehamilan yang dianggap berisiko tinggi dan aborsi yang tidak aman karena kehamilan tidak diinginkan. Keluarga Berencana dapat mencegah penyebab kematian ibu sekitar 28\%-30\% kehamilan dengan risiko tinggi karena hamil pada usia muda, hamil pada usia tua, jarak antar kehamilan yang terlalu pendek (kurang 
dari 2 tahun), dan paritas tinggi.(Starbird E, dkk. 2016)(Cleland J, dkk.2012)(Weaver EH,dkk.2013)

Pentingnya Keluarga Berencana dalam membantu mengatasi permasalahan terhadap kesehatan ibu maka perlu menjadi perhatian. Bentuk perhatian Keluarga Berencana selalu identik dengan penggunaan kontrasepsi. Penggunaan kontrasepsi menurut Survei Demografi dan Kesehatan Indonesia tahun 2017 mengalami kenaikan bila dibandingkan dengan tahun 2012. Namun, penggunaan kontrasepsi modern mengalami penurunan. Penggunaan tersebut pada tahun 2012 tercatat sekitar $57,9 \%$ sedangkan di tahun 2017 tercatat 57,2\%. Pemakaian kontrasepsi bila dilihat berdasarkan wilayah untuk perkotaan lebih rendah daripada perdesaan yaitu $55 \%$ untuk perkotaan dan $59 \%$ untuk pedesaan.(BPS,BkkbN,Kemenkes.2012 dan 2017)

Pemakaian kontrasepsi modern di Provinsi Banten tercatat 57,3\%. Namun metode kontrasepsi jangka pendek masih menjadi pilihan utama dalam layanan Keluarga Berencana. Kontrasepsi yang paling diminati oleh wanita menikah adalah suntik KB $(37,3 \%)$. Berbeda dengan kontrasepsi jangka panjang yang didapatkan bahwa kontrasepsi seperti IUD dan implan hanya sekitar 2,9\% dan 2,4\%.(BPS,BkkbN,Kemenkes. 2017)

Hasil kajian dari Misnaniarti dkk dan Sharjabad dkk dalam studinya menyatakan bahwa tingkat pendidikan seseorang mempengaruhi penggunaan kontrasepsi. Semakin rendah tingkat pendidikan maka semakin rendah pula dalam penggunaan kontrasepsi. (Sharjabad FN,dkk.2013) (Misnaniarti AD. 2016) Namun, Faktor pendidikan mengalami perubahan pada saat ini. Berdasarkan Survei Demografi dan Kesehatan (2017) didapatkan bahwa pemakaian kontrasepsi paling tinggi terdapat pada kalangan pendidikan SD yaitu 64\%. Pemakaian kontrasepsi modern menurun sejalan dengan meningkatnya pendidikan. (BPS,BkkbN,Kemenkes. 2017) Tujuan penelitian ini adalah untuk mengetahui faktor-faktor yang mempengaruhi penggunaan kontrasepsi di wilayah pedesaan.

\section{METODE}

Penelitian ini merupakan penelitian deskriptif kualitatif yang dilakukan untuk mengetahui faktorfaktor penggunaan alat kontrasepsi di 
pedesaan. Jumlah sampel yang Demografi dan Kesehatan Indonesia digunakan pada penelitian ini adalah (SDKI) tahun 2017 untuk wilayah 221 Wanita Usia Subur. Jenis data yang digunakan pada penelitian ini adalah data sekunder. Sumber data yang Provinsi Banten. Data dianalisis secara univariabel dan bivariabel dengan uji chi-square.

digunakan adalah data dari Survei

\section{HASIL DAN PEMBAHASAN}

Tabel 1. Penggunaan Metode Kontrasepsi berdasarkan kelompok tertentu di wilayah Pedesaan

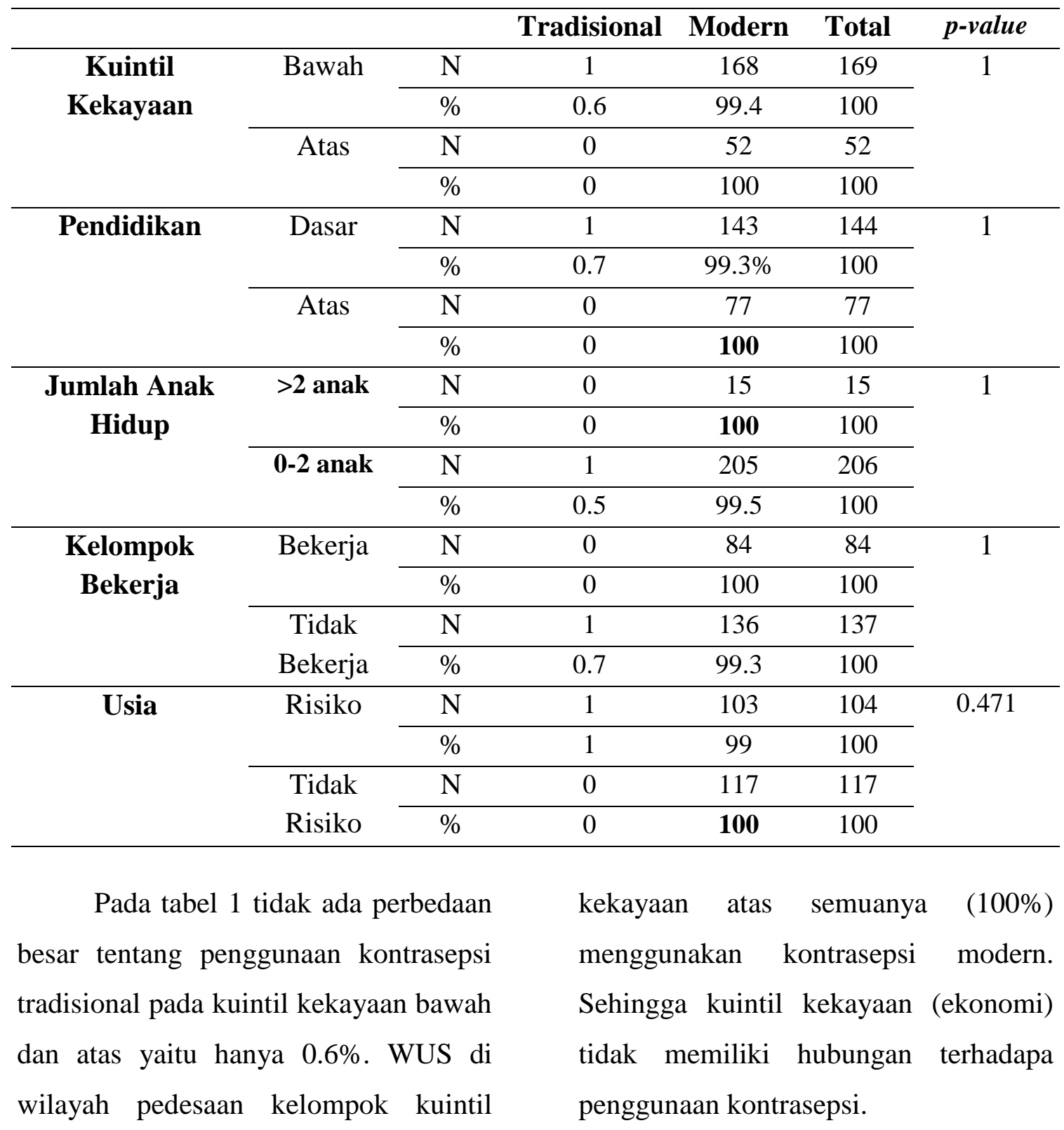


Penggunaan kontrasepsi tradisional pada WUS pendidikan dasar dan atas sangat sedikit yaitu dengan selisih $0.7 \%$. Sehingga tingkat pendidikan tidak memiliki hubungan terhadapa penggunaan kontrasepsi.

Semua responden $(100 \%)$ di wilayah pedesaan pada kelompok WUS dengan jumlah anak lebih dari (>) 2 orang sudah menggunakan kontrasepsi modern sehingga tidak terdapat hubungan yang signifikan antara jumlah anak hidup dengan penggunaan metode kontrasepsi baik diwilayah perkotaan maupun di pedesaan.

Pada kelompok bekerja dan tidak bekerja untuk penggunaan kontrasepsi tradisional tidak memiliki perbedaan yang besar $(0.7 \%)$ sehingga hampir tidak ada perbedaan. Sedangkan pada kelompok usia menunjukkan bahwa kontrasepsi tradisional hanya $1 \%$ digunakan oleh kelompok usia berisiko dan usia tidak memiliki hubungan terhadapa penggunaan kontrasepsi.

Penggunaan kontrasepsi ini salah satunya dipengaruhi oleh adanya tenaga kesehatan yang selalu memperhatikan wilayah tersebut. Berdasarkan penelitian Weaver EH, dkk menyatakan bahwa Program bidan desa dapat mempengaruhi dalam pemilihan metode kontrasepsi. Hal ini terbukti dari banyaknya wanita yang beralih dari kontrasepsi tradisional ke kontrasepsi modern jenis suntik. (Triyanto L,dkk. 2018)

Tingkat pendidikan mempengaruhi seseorang dalam menggunakan metode kontrasepsi. WUS dengan pendidikan tinggi akan menggunakan metode kontrasepsi jangka panjang dibandingkan dengan pendidikan rendah. (Rebecca H,dkk. 2013) Hal ini terjadi pada wilayah pedesaan, bahwa semua (100\%) WUS dengan pendidikan atas atau tinggi menggunakan kontrasepsi jenis modern.

Penggunaan kontrasepsi pada usia lebih dari 40 tahun diharapkan untuk membatasi bahkan menghentikan kelahiran. Sedangkan usia di bawah 20 tahun penggunaan kontrasepsi digunakan untuk menunda kehamilan sampai batas usia aman yaitu $\geq 20$ tahun. Oleh karena itu, penggunaan jenis kontrasepsi yang dibutuhkan adalah aman dan efektif untuk mencegah kehamilan. Hasil penelitian Triyanto dan Indriani (2018) di dapatkan bahwa usia mempengaruhi dalam pemilihan jenis kontrasepsi. Usia yang sudah tidak lagi reproduksi dengan baik akan memilih metode kontrasepsi jangka 
panjang.(SDKI Provinsi Banten.2017)

Hal ini terjadi pada wilayah pedesaan, semua wanita usia subur yang memiliki usia tidak berisiko semuanya menggunakan kontrasepsi modern $(100 \%)$.

Semua WUS dengan jumlah anak $>2$ dan bekerja sudah semuanya menggunakan kontrasepsi modern. Hasil di wilayah pedesaan tersebut sesuai dengan penelitian dari Triyanto dan Indriani (2018) tentang pemilihan metode kontrasepsi bahwa kelompok bekerja lebih banyak menggunakan kontrasepsi modern jangka panjang yaitu IUD. (Triyanto L,dkk.2018)

Hasil SDKI 2017 di Provinsi Banten, menunjukkan bahwa di wilayah pedesaan peran Bidan, Petugas KB, dan tokoh masyarakat lebih berperan dalam membantu WUS untuk menentukan penggunaan kontrasepsi.

\section{SIMPULAN}

Berdasarkan penelitian dapat disimpulkan bahwa mayoritas Wanita Usia Subur di wilayah pedesaan sudah menggunakan kontrasepsi Modern. Penggunaan kontrasepsi di wilayah pedesaan ini tidak dipengaruhi oleh kuintil kekayaan, pendidikan, jumlah anak hidup, kelompok bekerja, dan usia.

\section{UCAPAN TERIMA KASIH}

Peneliti ucapkan terima kasih kepada BKKBN Pusat yang telah memberikan Hibah Penelitian sehingga penelitian ini dapat terselesaikan dengan tepat waktu.

\section{DAFTAR PUSTAKA}

BPS, BkkbN, Kemenkes. Survey demografi kesehatan Indonesia. Jakarta. 2012 2017

BPS, BkkbN, Kemenkes. Survey demografi kesehatan Provinsi Banten. Banten. 2017

Cleland J, Agudelo AC, Peterson H, Ross J, Tsui A. Contraception and health. Lancet. 2012; 380: 149-56

Misnaniarti, Ayuningtyas D. Unmet need for family Planning in Indonesia and the policy strategy of intervention in several countries. International Journal of Reproduction, Obstetrics and Gynecology. Juni 2016;5 (6): 1680-1685

Rebecca H. Allen MD MPH, Carrie A. Cwiak MD MPH, Andrew M. Kaunitz MD. Contraception in women over 40 years of age. CMAJ, April 16, 2013, 185(7), Hal: $\quad 565-573 . \quad$ DOI:10.1503 /cmaj.121280 
https://www.cmaj.ca/content/cmaj

/185/7/565.full.pdf

Sharjabad FN, Yahya SZS, HA,

Muhamad, Hanafiah, Manaf RA.

Barriers of Modern Contraceptive

Practices among Asian Women: A

Mini Literature Review. Global

Journal of Health Science. 2013; 5

(5):181-192

Starbird E, Norton M, Marcus R.

Investing in family planning: key

to achieving the sustainable

development goals. Global Health:

Science and Practice. 2016; 4 (2):

$191-210$

Triyanto L, Indriani D. faktor yang mempengaruhi penggunaan jenis metode kontrasepsi jangka panjang (MKJP) pada wanita menikah Usia Subur di Provinsi Jawa Timur. The Indonesian Journal Public Health. Vol 13.No

2. Desember 2018. Hal $244-255$ )

Weaver EH, Frankenberg E, Fried BJ, Thomas D, Wheeler SB, Paul JE. Effect of village midwife program on contraceptive prevalence and method choice in Indonesia. Stud Fam Plann. 2013; 44 (4): 389-409 